\title{
FORMULASI DAN UJI MUTU FISIK PASTA DARI AIR PERASAN RIMPANG LENGKUAS MERAH (Alpinia purpurata $K$. Schum) SEBAGAI PENGHAMBAT JAMUR Malassezia furfur PENYEBAB PANU
}

\author{
Rina Asrina ${ }^{1}$ \\ Jurusan Farmasi Politeknik Sandi Karsa ${ }^{1}$
}

\begin{abstract}
ABSTRAK
Rimpang lengkuas sangat familiar di masyarakat, ada rimpang yang merah dan ada yang putih. Namun menurut hasil penelitian, rimpang lengkuas yang lebih efektif untuk menghambat jamur Malassezia furfur penyebab panu yaitu rimpang lengkuas merah (Alpinia purpurata K. Schum). Tujuan dari penelitian ini yaitu untuk membuat formula pasta dari air perasan rimpang lengkuas merah (Alpinia purpurata K. Schum) dengan mutu fisik yang baik. Penelitian ini termasuk jenis penelitian eksperimen laboratorium yang dilakukan di Laboratorium Farmasetika Jurusan Farmasi Politeknik Sandi Karsa Makassar. Metode penelitian meliputi formulasi sediaan pasta dari rimpang lengkuas merah yang sebelumnya telah diparut dan diperas airnya. Pasta yang dihasilkan kemudian diuji secara fisik. Hasil yang diperoleh yaitu sediaan salep berwarna putih sedikit kemerahan, bau khas lengkuas dengan bentuk semi padat, pasta homogen, bebas dari butiran kasar, $\mathrm{pH}$ sediaan yaitu pH 5, viskositas

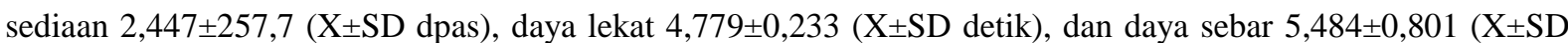
$\mathrm{cm})$. Semua pengujian yang dilakukan memenuhi syarat literatur sehingga disimpulkan bahwa air perasan rimpang lengkuas merah dapat membentuk sediaan pasta dengan mutu fisik yang baik.
\end{abstract}

Kata Kunci: Formulasi, Mutu fisik, Pasta, Air perasan, Rimpang lengkuas merah

Coresponden Author:

Rina Asrina

rheyzmizzath@gmail.com 


\section{PENDAHULUAN}

\section{A. Latar Belakang}

Indonesia dengan kondisi geografis sebagai negara beriklim tropis dengan suhu dan kelembaban yang cukup tinggi memudahkan jamur untuk berkembang biak sehingga infeksi oleh jamur banyak sekali terjadi. Salah satu penyakit akibat infeksi jamur adalah Pitiriasis versikolor dikenal oleh masyarakat di Indonesia dengan sebutan panu. Penyakit panu merupakan infeksi mikosis superfisial yang prevalensinya cukup tinggi sekitar 30-40\% di daerah tropis dan merupakan penyakit infeksi jamur terbanyak kedua tertinggi di Indonesia.

Rimpang lengkuas sangat familiar di masyarakat Indonesia. Terdapat dua jenis lengkuas yaitu varietas dengan rimpang umbi berwarna putih (Alpinia galanga $\mathrm{L}$.) dan varietas berimpang umbi merah (Alpinia purpurata $\mathrm{K}$. Schum). Menurut Budiarti (2007) pada lengkuas merah memiliki kandungan minyak atsiri dan komponen antijamur sedikit berbeda dan memiliki konsentrasi yang lebih tinggi dibandingkan pada lengkuas putih.

Sesuai dengan pendapat Budiarti, lengkuas merah mengandung minyak atsiri. Minyak atsiri pada lengkuas merah tersusun atas metal-silamat $48 \%$, seneol $20-30 \% 1 \%$ kamfer, dan sisanya galangin, eugenol senyawa terpenoid (sesquiterpen dan monoterpen). Senyawa flavonoid, zat resin seperti galangol, amilum, kadinen, dan heksa-hidrokadalen hidrat.

Salah satu senyawa bioaktif yang juga terkandung adalah 1'-asetoksi chavikol asetat (ACA) dan saponin terdapat pada lengkuas merah sedangkan pada lengkuas putih kandungan senyawa yang dimiliki adalah senyawa asam asetochavikol asetat (ACA), minyak atsiri dan terkandung pula zat resin seperti alpinin yang merupakan jenis flavanon yang dikenal sebagai senyawa fungistatik dan fungisida (Permadi, 2008).

Berdasarkan hasil penelitian yang dilakukan oleh Violita, dkk. (2013) menyatakan bahwa rimpang lengkuas merah (Alpinia purpurata K. Schum) lebih efektif untuk menghambat pertumbuhan jamur Malassezia furfur penyebab panu dibandingkan lengkuas putih (Alpinia galanga L.). Konsentrasi yang digunakan pada air perasan lengkuas merah dan air perasan lengkuas putih yaitu $20 \%, 40 \%, 60 \%$, $80 \%$, dan $100 \%$. Ukuran rerata diameter zona hambat lengkuas merah: $11,25 \mathrm{~mm} ; 12,5 \mathrm{~mm}$; $14,5 \mathrm{~mm} ; 15 \mathrm{~mm} ; 17,5 \mathrm{~mm}$ lebih besar dari lengkuas putih: $10 \mathrm{~mm} ; 10,75 \mathrm{~mm} ; 11,5 \mathrm{~mm}$; $12,25 \mathrm{~mm} ; 12,75 \mathrm{~mm}$. Hasil uji statistik one way
Anova menunjukkan perbedaan zona hambat yang signifikan.

Penggunaan rimpang lengkuas secara empiris tidak mempunyai dosis terukur, sehingga memungkinkan adanya efek samping yang terjadi. Oleh karena itu pada penelitian ini dibuat suatu formula pasta yang bisa digunakan dengan lebih efektif dan efisien. Kelebihan pasta dibanding sediaan topikal yang lain yaitu bahan obat dalam sediaan pasta lebih melekat pada kulit sehingga meningkatkan daya kerja lokal, konsentrasi pasta lebih kental dari salep, dan daya absorpsi pasta lebih besar dan kurang berlemak dibandingkan dengan sediaan salep (Lachman, 1994).

\section{B. Rumusan Masalah}

Berdasarkan latar belakang diatas maka masalah yang timbul adalah bagaimana cara memformulasi pasta dari air perasan rimpang lengkuas merah (Alpinia purpurata K. Schum) dengan mutu fisik yang baik?

\section{Tujuan Penelitian}

Penelitian ini bertujuan untuk membuat formula pasta dari air perasan rimpang lengkuas merah (Alpinia purpurata K. Schum) dengan mutu fisik yang baik.

\section{Manfaat Penelitian}

Memberikan data ilmiah tentang formulasi sirup dari pasta dari air perasan rimpang lengkuas merah (Alpinia purpurata K. Schum) sehingga salah satu bahan obat tradisional yaitu rimpang lengkuas merah dapat dikembangkan menjadi bentuk sediaan pasta dengan mutu fisik yang baik.

\section{METODE PENELITIAN}

\section{A. Jenis Penelitian}

Jenis penelitian ini yaitu penelitian eksperimen labiratorium untuk mengetahui formulasi pasta dari air perasan rimpang lengkuas merah (Alpinia purpurata K. Schum) dengan mutu fisik yang baik.

\section{B. Lokasi dan Waktu Penelitian}

Penelitian ini dilakukan pada Bulan Oktober 2020 di Laboratorium Farmasetika Jurusan Farmasi Politeknik Sandi Karsa Makassar.

\section{Alat dan bahan}

Alat yang digunakan dalam penelitian ini adalah alat-alat gelas (pirex), alat uji daya lekat, alat uji daya sebar, mixer (Cosmos), indikator $\mathrm{pH}$ 
universal, timbangan analitik (Mettler Toledo), Viskometer Rion.

Bahan yang digunakan dalam penelitian ini adalah air perasan lengkuas merah, amilum manihot, nipagin, vaselin alba, zink oksida.

Tabel I. Rancangan Formula, tiap 30gram pasta mengandung:

\begin{tabular}{lc}
\hline \multicolumn{1}{c}{ Bahan } & Konsentrasi Bahan \\
\hline Air perasan lengkuas merah & $20 \%$ \\
\hline Amilum manihot & $3 \mathrm{~g}$ \\
\hline Nipagin & $0,05 \mathrm{~g}$ \\
\hline Zink oksida & $12,5 \mathrm{~g}$ \\
\hline Vaselin alba & ad 30g \\
\hline
\end{tabular}

\section{Desain Penelitian}

1. Pembuatan Pasta

Amilum Manihot, zink oksida dan nipagin diaduk di dalam lumpang, ditambahkan air perasan lengkuas merah, diaduk lagi, terakhir ditambahkan leburan vaselin alba, diaduk sampai terbentuk massa pasta.

2. Evaluasi Pasta

a. Organoleptis

Meliputi bentuk, warna, bau dan bentuk dari sediaan pasta sehingga diketahui tampilan dari sediaan tersebut dalam keadaan baik. Dilakukan dengan cara melihat warna, mencium bau dan mengamati bentuk dari sediaan pasta (Nayeem, 2011)

b. Uji Homogenitas

Pasta dioleskan pada tiga buah objek gelas untuk diamati homogenitasnya dibawah sinar. Apabila tidak terdapat butiran - butiran kasar diatas obyek gelas tersebut maka pasta yang diuji dinyatakan homogen.

c. $\mathrm{Uji} \mathrm{pH}$

Pengukuran $\mathrm{pH}$ dilakukan dengan cara mencelupkan strip indikator unversal kedalam sediaan pasta piroksikam kemudian diamati perubahan warna pada strip indikator (Jufri, 2012).

d. Uji Viskositas

Sebanyak 100 gram sediaan pasta diuji viskositas menggunakan viskositas Brookfield. Celupkan spindle nomor 64 ke dalam sediaan pasta dan atur kecepatan 5 rpm kemudian diamati viskositas sediaan pada monitor alat (Aswal, 2013).

e. Uji Daya Lekat

Sebanyak $250 \mathrm{mg}$ pasta diratakan pada salah satu gelas objek kemudian ditutup dengan gelas objek yang lain. Setelah itu, tindihan dengan beban $1 \mathrm{~kg}$ selama 5 menit. Pasangan gelas objek ini kemudian dipasangkan pada alat uji daya lekat dan bersamaan dengan pemberian beban pada alat uji daya lekat $1 \mathrm{~kg}$ dan stopwatch dinyalakan. Waktu dihitung mulai dari pemberian beban dan beban dihentikan ketika gelas objek tersebut terlepas (Nayeem, 2011).

f. Uji Daya Sebar

Sebanyak 0,5 gram pasta diletakkan di tengah petri kemudian petri yang satu diletakkan di atasnya dibiarkan selama satu menit. Diameter pasta yang menyebar diukur dengan menggunakan penggaris, kemudian ditambahkan 50 gram beban tambahan dan didiamkan satu menit, lalu diukur diameter pasta yang menyebar (Aswal, 2013).

\section{HASIL DAN PEMBAHASAN}

\section{A. Hasil Penelitian}

Hasil Uji Evaluasi Sediaan:

1. Uji organoleptis yaitu sediaan salep berwarna putih sedikit kemerahan, bau khas lengkuas dengan bentuk semi padat.

2. Uji homogenitas menunjukkan pasta yang homogen, bebas dari butiran kasar

3. Uji $\mathrm{pH}$ diperoleh $\mathrm{pH}$ sediaan yaitu $\mathrm{pH} 5$.

4. Uji viskositas diperoleh viskositas sediaan 2,447 $\pm 257,7$ (X \pm SD dpas)

5. Uji daya lekat diperoleh $4,779 \pm 0,233$ $(\mathrm{X} \pm \mathrm{SD}$ detik)

6. Uji daya sebar diperoleh $5,484 \pm 0,801$ $(\mathrm{X} \pm \mathrm{SD} \mathrm{cm})$.

\section{B. Pembahasan}

Salah satu penyakit akibat infeksi jamur adalah penyakit panu (Pitiriasis Versikolor). Penyakit panu merupakan infeksi mikosis superfisial yang prevalensinya cukup tinggi sekitar 30-40\% di daerah tropis dan merupakan penyakit infeksi jamur terbanyak kedua tertinggi di Indonesia (Kristanty, 2005).

Secara empiris, rimpang lengkuas banyak digunakan sebagai obat panu. Rimpang lengkuas sangat familiar di masyarakat Indonesia, baik sebagai bumbu masak maupun sebagai obat. Terdapat dua jenis lengkuas yaitu lengkuas putih banyak digunakan sebagai bumbu masak, sedangkan lengkuas merah berkhasiat sebagai obat.

Berdasarkan penelitian yang dilakukan oleh Violita, dkk. (2013) menyatakan bahwa rimpang lengkuas merah lebih efektif terhadap jamur Malassezia furfur penyebab panu dibandingkan lengkuas putih, sehingga pada penelitian ini digunakan lengkuas merah dengan 
konsentrasi $20 \%$ karena pada konsentrasi ini lengkuas merah sudah mampu menghambat pertumbuhan jamur Malassezia furfur.

Formulasi sediaan dibuat dalam bentuk pasta. Kelebihan pasta dibanding sediaan topikal yang lain yaitu bahan obat dalam sediaan pasta lebih melekat pada kulit sehingga meningkatkan daya kerja lokal, konsentrasi pasta lebih kental dari salep, dan daya absorpsi pasta lebih besar dan kurang berlemak dibandingkan dengan sediaan salep. Selain itu, zat aktif sediaan merupakan minyak atsiri (minyak menguap) sehingga diharapkan dengan bentuk pasta yang padat mampu menahan laju penguapan dari zat aktif tersebut.

Zink oksida dalam formula selain sebagai dasar pasta, juga merupakan salah satu mild astringent dengan kajian farmakologis sebagai antiseptik lokal. Mild astringent yang dimaksud adalah mengecilkan jaringan kulit sehingga dapat melindungi jaringan kulit. Zink Oksida dalam pasta ini dimaksudkan untuk menormalkan ketidakseimbangan fungsi kulit, membantu mencegah kelainan, dan meregulasi kelenjar sebacea (Morkoc, 2009).

Amilum digunakan sebagai pembentuk pasta dengan $\mathrm{pH}$ 5,5 mirip dengan $\mathrm{pH}$ Zink oksida (Wilkins, 2000). Pada penelitian ini digunakan pati singkong atau amilum Manihot. Amilum singkong merupakan amilum yang mudah terhidrolisis oleh enzim $\alpha$-amilase yang selanjutnya akan berpengaruh terhadap sifat fisik amilum (Rocha, 2010).

Nipagin digunakan sebagai pengawet, pada formula sediaan pasta ini dibutuhkan pengawet karena zat aktifnya berupa air perasan sehingga mudah ditumbuhi mikroorganisme.

Vaselin alba digunakan sebagai pembentuk pasta dengan massa yang sedikit berlemak, ditambahkan setelah dilelehkan terlebih dahulu sehingga mampu mengikat semua bahan padat dari pasta.

Stabilitas fisik sediaan pasta dapat diketahui dengan melakukan evaluasi fisik terhadap sediaan pasta yang telah dibuat. Evaluasi sediaan pasta yang dilakukan yaitu uji organoleptis, uji homogenitas, uji pH, uji viskositas, uji daya lekat, dan uji daya sebar. Pada uji organoleptis diperoleh pasta berbentuk semi padat, berwarna putih sedikit kemerahan, dengan bau khas lengkuas. Pada uji homogenitas menunjukkan pasta yang homogen dan bebas dari butiran kasar. Pada uji $\mathrm{pH}$ diperoleh bahwa $\mathrm{pH}$ sediaan yaitu 5 , sesuai dengan rentang $\mathrm{pH}$ yang tidak mengiritasi kulit yaitu 4,5 - 6 sehingga aman digunakan. Uji viskositas diperoleh viskositas sediaan 2,447 $\pm 257,7$ ( $\mathrm{X} \pm \mathrm{SD}$ dpas). Pada uji daya lekat menunjukkan formula memiliki daya lekat yang baik karena memiliki daya lekat lebih dari 1 detik. Pada uji daya sebar menunjukkan formula sediaan memiliki daya sebar yang baik karena memasuki rentang 5-7 $\mathrm{cm}$.

\section{PENUTUP}

\section{A. Kesimpulan}

Berdasarkan hasil penelitian yang telah dilakukan terhadap formulasi sediaan pasta yang mengandung rimpang lengkuas merah (Alpinia purpurata K. Schum), maka dapat disimpulkan bahwa formula tersebut dapat membentuk sediaan pasta dengan mutu fisik baik.

B. Saran

Karena sebelumnya hanya menguji efektivitas antijamur dari air perasan rimpang lengkuas merah, maka perlu dilakukan penelitian lebih lanjut mengenai uji efektivitas antijamur dari rimpang lengkuas merah yang sudah dibuat dalam bentuk pasta

Perlu dilakukan penelitian lebih lanjut mengenai kestabilan pasta yang mengandung sari lengkuas merah

\section{DAFTAR PUSTAKA}

Aswal A, Kalra M, Rout A. 2013. Preparation and Evaluation of Polyherbal Cosmetic Cream. Pharm Lett. 2013. 5(1):83-8.

Budiarti, Rini. 2007. Pemanfaatan Lengkuas Merah (Alpinia purpurata K. Schum) sebagai Bahan Anti Jamur dalam Sampo. Skripsi Sarjana. Fakultas Teknologi Pertanian Institut Pertanian Bogor. Bogor.

Jufri M., Anwar E., Utami P. M. 2012. Uji Stabilitas Sediaan Mikroemulsi Menggunakan Hidrolisat Pati (De 35-40) Sebagai Stabilizer. Pharm Sci Res PSR. 2012. 3(1)

Lachman, L., Lieberman., and Kanig, J. L. 1994. Teori dan Praktek Farmasi Industri. Jilid 2. Edisi 3. Diterjemahkan oleh Siti Suyatmi. UI Press. Jakarta. 1091-1096, 1119-1120.

Kristanty, Roro Inge Ado. 2005. Identifikasi Spesies Malassezia pada Pasien Pitriasis versikolor dengan Cara Pemeriksaan Morfologi dan Sifat Biokimia di Departemen Ilmu Kesehatan dan Kelamin Rumah Sakit Cipto Mangunkusumo Jakarta. Tesis. Universitas Indonesia. Jakarta. 
Nayeem N, Md. K. 2011. Stability studies and evaluation of the semi solid dosage form of the rutin, quercitin, ellagic acid, gallic acid and sitosterol isolated from the leaves of Tectona grandis for wound healing activity. Arch Appl Sci Res. 2011. 3(1):43-51.

Morkoc, H. 2009. Zinc Oxide Fundamentals, Materials, and Device Technology. Wiley VCH. Verlag GmbH, 77.

Permadi, Adi. 2008. Membuat Kebun Tanaman Obat. Pusaka Bunda (Anggota Ikapi). Depok.

Rocha, Ó. D. S., Carneiro, Franco, C. M. L. 2010. Effect of Enzymatic Hydrolysis on Some Physicochemical Properties of Root and Tuber Granular Starches. Ciênc. Tecnol. Aliment., Campinas, 30 (2): 544-551

Violita, Yessika, Sri Wantini, Eka Sulistianingsih. 2013. Perbandingan Uji Efektivitas Air Perasan Lengkuas Merah (Alpinia purpurata K. Schum) Dengan Air Perasan Lengkuas Putih (Alpinia galnga L. Wild) Terhadap Pertumbuhan Jamur Malassezia furfur Penyebab Panu. Jurnal. Jurusan Analis Kesehatan. Politeknik Kesehatan Kemenkes Tanjungkarang.

Wilkins, Williams Lippincott. 2000. Remington. Conggres library Office, United State of America 